\title{
Managerial Communication System for the Operation of Learning Acceleration Programs
}

\author{
Miftakhul Huda \\ Universitas Muhammadiyah Surakarta, Indonesia
}

Corresponding Author: Miftakhul Huda,_amiftakhul.huda@ums.ac.id

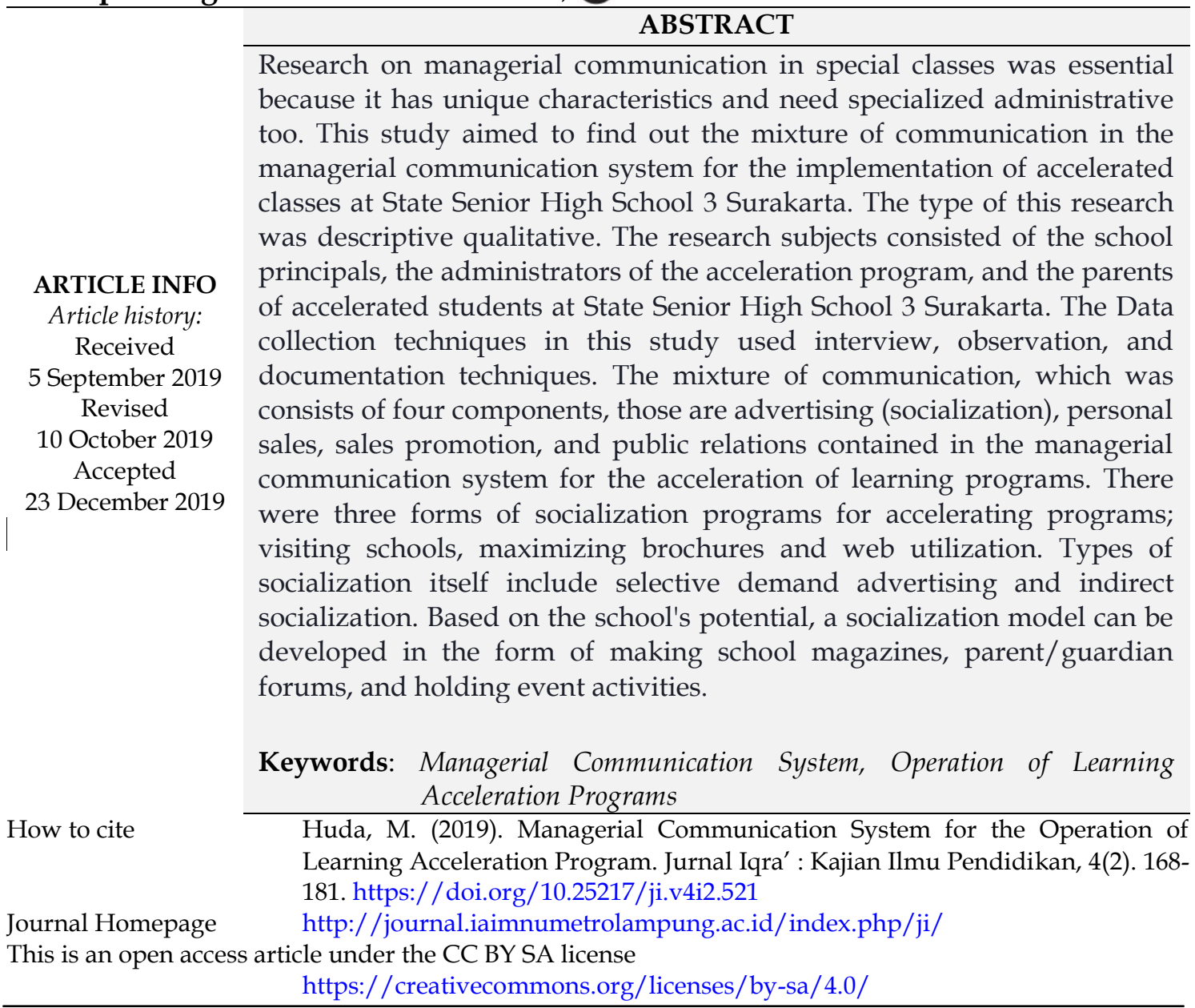

\section{INTRODUCTION}

Education is a process of transfer of knowledge and transfer of values. The transfer of knowledge is related to various experiences. The removal of benefits related to the formation of human attitudes and character. The alteration of consciousness and interests in education can be carried out between educators, students, and the educational environment (Rumsey, 2018; Cao, Postareff, Lindblom-Ylänne, \& Toom, 2019). The transfer of knowledge and competency to students can be adequately carried if education places students according to each student's characteristics. Competencies include values, self-regulation skills, motivation, and particular knowledge (Weber, 
Gold, Prilop, \& Kleinknecht, 2018). In the education system, students cannot be treated equally by educators (Singer, 2018; Alkhalaf et al., 2012). It means that educators must not ignore the different characteristics of each student. Some researchers agree that naturally, students have a unique character namely has an individual diversity between one another in various ways (Vanderheyden \& De Baets, 2015; Dare \& Nowicki, 2018; Murray., 2018). Such diversity includes the diversity of intelligence, talent, personality, and physical condition. In terms of a variety of data, for example, each student has different knowledge (Landau, Hodges, \& Mctigue, 2019; Antonio et al., 2014). The difference must be addressed wisely by giving the appropriate treatment by the portion of the student. Yenice \& Aktamış (2010) reported students who have less intelligence should not be ignored by providing the same treatment as high-intelligence students. If in a high-intelligence student learning can take two stages, educators should contain three or four steps to students with low intelligence (Post \& Molen, 2018; Beceren, 2010; Akbari \& Hosseini, 2008). The aim of this obligation is all students should gain full understanding and knowledge and also the diversity of talent and personality (Allen, 2015; Dunn et al., 2009). Thus, educators must not ignore the different characteristics of the students.

The various treatments must be concerning life as an effort of understanding that students have the diversity of the characteristics. Based on the variety of these characteristics, an accelerated learning program (after this referred to as acceleration), for students who have high average intelligence. The researchers found some problems related to the acceleration program at State Senior High School 3 Surakarta, namely the opinion of some communities who thought that the acceleration program was a trial program. Because students felt pressured in the acceleration program due to the compaction time, students' less interaction with the environment, and the high school fees. Those problems showed the lack of communication in between parties related to the organization of the acceleration program. Intrinsically, mixture communication consists of advertising, personal selling, sales promotion, and public relations (Kotler, 2007; Agih, 2015). Therefore these factors should become mutually support in communicating an acceleration program to the community.

Some previous research that was relevant to this research was conducted by Ohlsson (2018), which built and confirmed basic competencies that were considered necessary for teachers who teach using accelerated learning. This research was conducted by surveying the teachers who had participated in the accelerated learning process. The study looked at the competencies prepared by teachers. Furthermore, the research conducted by Conde (2006) entitled "Patterns of Verbal Communication in Children with Special Needs" (Verbal 
Communication Patterns in Children with Special Needs). The aim of this study was testing social interactions between children with special needs, children who were challenging to learn, and abnormal children who need special attention, investigating the verbal language characteristics of these children. The similarity between this Research and Conde's research was highlighting the education of children with special needs, especially gifted children. And the difference to this research was that Conde examines patterns of verbal communication carried out by children with special needs in everyday life. While this research focused on managerial communication in the administration of education for children with special needs.

Harjaningrum \& Inayati (2007) conducted research entitled "The Role of Parents and Practitioners in Helping the Growth of Talented Children through Understanding Educational Theories and Trends." This study concluded that the role of parents and practitioners was very influential in the growth of gifted children. The development of gifted children can be planned early on by using the concept of multiple intelligence. The educational material, method, or curriculum needs to be adapted to the character of gifted children. Harjaningrum's research has similarities with this research, which focuses on the education of talented children. And the difference was Harjaningrum's research examined the process of developing the ability of gifted children while this study examined the communication system of class administration for talented children.

This research was essential to be done to communicate the managerial implementation of the acceleration class. Thus, there is a common perception between schools, government, and the community towards the implementation of the acceleration program. The perception of equality that appears positively can act as a means of control for schools so as not to abuse the acceleration program for purposes that are not following the legislation. On the other hand, good managerial communication will foster public confidence in the implementation of the acceleration program. Based on this research is needed on a model of managerial communication systems in the organization of accelerated classes. This study examines the mixture communication model used by schools to communicate acceleration programs to the community.

\section{RESEARCH METHODOLOGY}

This research was qualitative. It based on the type of research data in the form of qualitative data. This study has four groups of research subjects. The research subject was the main source of research data, which has data on the variables studied (Azwar, 2007; Moser \& Korstjens, 2018). Those four groups 
were the principal and the manager of the acceleration program, the teacher who tought in the acceleration class, the acceleration student, and the parents of the students in the acceleration program at State Senior High School 3 Surakarta

The data research was the information about the mixture of communication in the organization of the acceleration class. The sources of this research data were grouped into two types, informants and documentation. The informant consists of the principal and organizer of the acceleration program, acceleration teacher, acceleration student, and parents of acceleration students at State Senior High School 3 Surakarta. Documentation: Research Results of the Post-Year Grant I "Model for Developing Special Classes Managerial Communication Systems," school documents regarding the implementation of the acceleration program, mixture communication documents, and field documents

Data collection in this study used interviews, observation, documentation, and workshops. The informants interviewed were the school principal, organizer of the acceleration program, teachers, and students of the acceleration program at State Senior High School 3 Surakarta. Interview techniques were used to explore data on advertising models, personal sales, promotions, and public relations that have been carried out by schools, which include planning, modeling conducted by schools, implementation, and evaluation. In addition, interview techniques were used to obtain data on community responses to the implementation of the mixture communication model. Observations were made on the application of meetings, learning activities, and the implementation of the acceleration program. It aims to see the managerial communication used in the administration of the program. Documentation in the form of post-grant research reports carried out in the first year and documents on the implementation of the acceleration program. The validity of the data in this study was tested using triangulation. Sutopo, (2002) distinguishes triangulation into four types; those are a triangulation of sources, techniques, investigators, and theories. The triangulation in this study is the triangulation of sources and techniques. The data analysis technique was carried out in several stages; those are data reduction, data display, concluding, and verification.

\section{RESULT AND DISCUSSION}

The mixture of communication is a system because it is in the form of a unit consisting of components or elements that influence each other to achieve certain goals. The intended purpose is to communicate the acceleration program to the public. In State Senior High School 3 Surakarta, the mixture of 
communication consisting of socialization, personal selling, sales promotion, and community relations are being interrelated with one another. Nevertheless, each component also stands as its system (Raia, 2018). Socialization stands as a system and has subordinate components, as well as personal sales, sales promotions, and public relations. Thus, when viewed from the mixture communication system, socialization, personal selling, sales promotion, and public relations are subsystems of the mixture communication system. These subsystems work together to form a communication system model.

\section{Socialization of the Implementation of the Acceleration Program}

The implementation of the acceleration program at State Senior High School 3 Surakarta has been going on since 2003. Thus, until 2010, the school, there have been eight batches of acceleration classes. During the eight years of the implementation of the acceleration program, the school certainly experienced several problems and needed an evaluation to overcome the problems. The negative perception that arises in some communities is thought of like the assumption that the acceleration program will make students unsociable with the environment and students less mature in mastering subject matter. The socialization model that has been carried out by State Senior High School 3 Surakarta to attract students into the acceleration program takes two forms; direct visits to target schools (: giving some brochures) and web use.

1) Socialization through brochures

The acceleration program brochure is used by State Senior High School 3 Surakarta as one of the media to attract students. The school designed the brochure in such a way that the community was interested in entering the acceleration program. The brochure contains several attractions from the acceleration program, including school photos, student photos (: activities in the laboratory and competitions in Singapore). Legal basis for the implementation of the acceleration program, extracurricular activities (: TOEFL, computers, papers, study visits, banding studies, social work practices, and training to face competition). Besides, the brochure presents information on admission of new students, which includes the time and place of registration, registration requirements, and the time of announcement of the results of the PSB selection. The brochure also presents a list of achievements achieved by acceleration students in several competitions and track records.

2) Socialization through the internet

Implementers of the acceleration program at State Senior High School 3 Surakarta used the internet to socialize the program. Unlike the brochure 
which only fully presents material about acceleration, the internet (: web) presents material about State Senior High School 3 Surakarta in general. Thus, information about the acceleration program on the web of State Senior High School 3 Surakarta becomes a shared part of the news. The web contains material about the profile of State Senior High School 3 Surakarta, student work, events, announcements, and polls regarding the development of IT. In the announcement section, information about acceleration appears at certain times; for example, when there are events that are carried out by acceleration students. It happens because the web is a school website. Thus, the web does not only contain about acceleration but also includes RSBI, regular, and other school news.

Based on web analytics, it needs to be designed by creating its features regarding the acceleration program. With its features, users have no trouble finding information about the acceleration program. Also, pre-existing news is not deleted. Another benefit is that the news can be grouped according to type, for example, acceleration news is in the acceleration feature, and RSBI news is in the RSBI feature.

The making of these features is needed in the socialization of the acceleration program. It is based on the consideration that there will be a web dissemination plan in the coming years. Socialization (advertising) can be divided into two types; primary demand advertising and selective demand advertising. The socialization of the acceleration program in State Senior High School 3 Surakarta includes selective demand advertising. Selective demand advertising is advertising that seeks to encourage demand for a type of product as a whole by mentioning the brand or manufacturer's name (Swastha, 2007). The acceleration program socialization is carried out by stating clearly the program offered in the acceleration program. Thus, the type of socialization is selective demand advertising. The type of socialization of the acceleration program is indirect socialization (advertising). Secondary socialization is socialization, which carried out by not expecting direct target responses.

The socialization of accelerate program runs in two ways; brochures and the internet can be developed with other alternatives. These alternatives can complete the existing models. Also, presenting other alternatives can reduce the perception of the community regarding the acceleration program. The following socialization models proposed by researchers are based on the potential of the school. The model can be alternative socialization that can be done by State Senior High School 3 Surakarta. The model is in the form of making school magazines, parent/guardian forums, and event activities. 


\section{Personal Selling the Implementation of the Acceleration Program}

According to the theory revealed by Kotler (2007), the main goal in personal selling is to establish good relations between schools and the community. Form of personal selling activities in the form of interacting directly between individuals and doing face-to-face to create, improve, or maintain good relations.

Personal selling is different from socialization. The socialization of the nature of its communication is mass communication (Anh, James, \& Pittock, 2018). However, the nature of communication from personal selling is individual communication. As such, private selling relies on the strength of individual school interactions with community members. Personal selling and outreach program can complete each other. Personal selling is a personal interaction to maintain good relations with the community. Personal interaction can be used as a way of socialization. Thus, the activity includes two objectives at once, namely maintaining good relations with the community and socializing the acceleration program. The meeting between the school and the community (: parents/guardians) has been held by the school. The meeting takes place periodically. Interpersonal interactions, namely school personnel (: teachers, program implementers, principals) with parents of students, have taken place informally. This interaction occurs during the process of implementing the acceleration program. Thus, indirectly, the element of personal selling has been in the management of the acceleration program.

Based on the potential of the school, the researcher proposes a personal selling model to complement the existing model. Schools can develop personal selling by facilitating interpersonal relationships. Schools can be a facility for personal relationships between students and prospective students, parents of accelerated students and parents of prospective accelerated students, and parents of one generation of acceleration students with parents of students of another generation of acceleration.

\section{Sales Promotion Organizing the Acceleration Program}

State Senior High School 3 Surakarta is one of the best high schools in Surakarta. This is based on the high-value requirements for admission to the school, academic achievement during student learning, and the level of outcome produced by the school. The high-value requirements for entering State Senior High School 3 Surakarta caused high competition between prospective students to enter the school, especially the acceleration program.

Based on the documentation data, some acceleration students show good academic achievement. Academic achievements include winning several 
competitions. Based on school documents, competitions that have been won by acceleration students include high school mathematics competition (hope I as Jeteng DIY), mechanics competition (II national), logic and programming competition (national IV), mathematics Olympiad (I Central Java), English writing contest (II of Central Java DIY), English debate contest (II of Central Java DIY), English news calling (II of Central Java DIY), student exemplary contest (II Central Java), and contest of young scientific work (III DIY Central Java).

The student graduation rate for each year is $100 \%$. The State Senior High School 3 Surakarta 100\% continue to study at universities, both domestic and abroad. This data is based on academic track record documents created by the acceleration program.

Data on the number of students entering the acceleration program, the academic achievement of students during the learning process, and the resulting graduate output is an indication of the quality of an educational program. Based on the data that has been described, the quality of State Senior High School 3 Surakarta is quite good enough. It causes the high value of public interest to put their children to study at this school, and this factor caused the school to find not to difficulties in terms of promotion. Nevertheless, based on observations, the school continued to carry out activities classified as a promotion.

The organizer of the acceleration program at State Senior High School 3 Surakarta made several excellent programs. The program indirectly became an attraction (: promotion) for society. The program includes scholarships, collaboration with universities, academic track records, evening classes, outbound psychology, and mentoring psychologists. Based on the analysis conducted on promotional activities, schools have the potential to develop their promotion programs.

\section{Public Relations Organization of the Acceleration Program}

Based on the theory revealed by Kotler (2007), public relations relates to increasing public trust through supporting publicity, fostering a good "school image," handling or counteracting rumors, stories, and events that harm schools. State Senior High School 3 Surakarta, especially the acceleration program, has tried to maintain its image in the society. A good image will lead to public confidence for the school. The school is trying to build a good image in the society.

This School tries to build a good image by creating a family atmosphere and making excellent programs that are acceptable by society. In addition, the 
school also built a good image with several junior high schools. This is needed by the school because the supply of new students comes from junior high schools.

Another important role that junior high school has to direct the students desire to enter the acceleration program. The desire of students to enter the acceleration program can be formed while still in middle school. Therefore, schools see the need to maintain imaging at junior high schools. The imagery is maintained by fostering good relations, and State Senior High School 3 Surakarta reported that the junior high school alumni are included in the acceleration program. Another model proposed by researchers to create a good image so that a good relationship is also created with transparency. This transparency can take the form of transparency in terms of program implementation or financial transparency (Rivers \& Ross, 2018). The transparency in the implementation of a certain program, for example, the schools involves the parents in planning the implementation program. In addition, the school reports the results of the implementation of parents. Financial transparency can be done by providing financial reports to parents.

The finding in this study was the mixture of communication that consists of four components (advertising; socialization, personal sales, sales promotion, and public relations) contained in the managerial communication system for the acceleration of learning programs. Good communication between the school and the community is needed. This is to overcome the emergence of negative perceptions regarding the implementation of the acceleration program (Levisen, 2016). The managerial communication system for the operactionl learning acceleration programs involves: socialization through brochure and internet, personal selling, sales promotion organizing, and public relation organization. Then, model socialization acceleration program devided into three types, namely visiting school, maximizing distribution brochure, and web utilization. The types of socialization itself include selective demand advertising and indirect socialization. The model socialization can be developed in creating school magazines, parent/guardian forums, and holding event activities. Good relations between schools and the community will lead to community trust in schools, especially in the implementation of the acceleration program (Kruel, Horne, Steenis, \& Penuel, 2018). Hence, in personal selling activities can be done directly interaction between individuals and doing face-to-face to create, improve, or maintain good relations.Promotional aspects in the mixture communication of the implementation of the acceleration program conducted by schools include the provision of scholarships, collaboration with universities, academic track records, outbound psychology, and mentoring psychologists. It 
appropriate with research by Kotler (2007) \& Agih (2015) who reported that advertising, personal selling, sales promotion, and public relations was several ways in acceleration program of school. Based on the potential of the school, the promotion model that can be developed by the school in cooperation with universities and foreign schools. Public relation was done by making a good image in the society. The Public relations that have been carried out by schools was to establish good relations with junior high school students. Good relations in the community can be done in several ways, such as financial transparency, discussing programs, and channeling aspirations.

This finding was in line with the findings of several previous studies for instance Jaggars, Hodara, Cho, \& Xu (2015), which reported there was the development of progam acceleration in terms of students' outcomes, classess, and implication. It was very needed to buid and confirm the basic competencies that were considered necessary for teachers who teach using accelerated learning (Ohlsson, 2018). But there was a difference aspect; this previous study examines the competence of teachers who teach in accelerated classes, while this current study focuses on the implementation of the acceleration program. Moreover, Hawadi (2004) studied Academic Stress in Student Accelerated Learning Programs. It reported that the majority of high school students in the accelerated learning program experienced moderate academic stress. There was a significant negative relationship between the perception of the implementation of the acceleration and self-efficacy programs with academic stress. There was a significant negative relationship between the dimensions of the teacher, the evaluation system, and counseling guidance with stress in the academic field; there is a significant negative relationship between the perception of the implementation of the acceleration program and self-efficacy with the dimensions of stress in academia. This previous research has relevance to current research, which studied the implementation of the acceleration program. Besides, most students in the acceleration program were getting moderate stress.

This research has implications for the form of muxture communication that is part of managerial communication in the administration of special classes. Education in Indonesia in the future will have many forms, so managerial communication is needed, either internal communication institutions or external communications involving the public in general.

\section{CONCLUSION}

The mixture of communication that consists of four components (advertising; socialization, personal sales, sales promotion, and public relations) 
contained in the managerial communication system for the acceleration of learning programs. Model socialization acceleration programs consist of three aspects, namely visiting school, maximizing distribution brochure, and web utilization. The types of socialization itself include selective demand advertising and indirect socialization. The model socialization can be developed in creating school magazines, parent/guardian forums, and holding event activities. Then in personal selling activities can be done directly interaction between individuals and doing face-to-face to create, improve, or maintain good relations. Promotional aspects in the mixture communication of the implementation of the acceleration program conducted by schools include the provision of scholarships, collaboration with universities, academic track records, night classes (in planning but already informed), outbound psychology, and mentoring psychologists.

The researchers provide several suggestions based on the results of research that has been done. The suggestion for program managers was to consider the development of information technology in managerial systems. It will make the implementation of the programs are more communicative. Furtheromre, for further researchers, there is the impact on the development of managerial communication systems if they have been added and equipped with information technology.

\section{ACKNOWLEDGMENTS}

The author was sincere appreciation to Drs. H. Makmur Sugeng as Head Master for Senior High School 3 Surakarta to give permission to conduct my research. Then, thanks for the guidance who has given motivation to author to immediately complete this research.

\section{AUTHOR CONTRIBUTION STATEMENTS}

The author had participated in the research and approved the final version of the manuscript.

\section{REFERENCES}

Agih, A. (2015). Effective School Management and Supervision: Imperative for Quality Education Service Delivery. African Research Review, 9(3), 62. https:/ / doi.org/10.4314/afrrev.v9i3.6

Akbari, R., \& Hosseini, K. (2008). Multiple intelligences and language learning strategies: Investigating possible relations. System, 36(2), 141-155. https:/ / doi.org/10.1016/j.system.2007.09.008

Azwar, Saifuddin. (2007). Metode Penelitian. Yogyakarta: Pustaka Pelajar. 
Alkhalaf, S., Drew, S., AlGhamdi, R., \& Alfarraj, O. (2012). E-Learning System on Higher Education Institutions in KSA: Attitudes and Perceptions of Faculty Members. Procedia - Social and Behavioral Sciences, 47, 11991205. https:/ / doi.org/10.1016/j.sbspro.2012.06.800

Allen, B. P. (2015). Personality Theories: Development, Growth, and Diversity. Psychology Press. Google Scholar

Anh, T., James, H., \& Pittock, J. (2018). Interaction Social learning through rural communities of practice : Empirical evidence from farming households in the Vietnamese Mekong Delta. Learning, Culture and Social Interaction, 16(October 2017), 31-44. https:/ / doi.org/10.1016/j.lcsi.2017.11.002

Antonio, T., Lanawati, S., Wiriana, T. A., \& Christina, L. (2014). Correlations Creativity, Intelligence, Personality, and Entrepreneurship Achievement. Procedia - Social and Behavioral Sciences, 115, 251-257. https:// doi.org/10.1016/j.sbspro.2014.02.433

Beceren, B. Ö. (2010). Determining multiple intelligences pre-school children (46 age) in learning process. Procedia - Social and Behavioral Sciences, 2(2), 2473-2480. https:/ / doi.org/10.1016/j.sbspro.2010.03.356

Cao, Y., Postareff, L., Lindblom-Ylänne, S., \& Toom, A. (2019). Teacher educators' approaches to teaching and connections with their perceptions of the closeness of their research and teaching. Teaching and Teacher Education, 85, 125-136. https:/ / doi.org/10.1016/j.tate.2019.06.013

Conde, J. M. (2006). Patterns of verbal communication in children with special needs. University of North Texas. Google Scholar

Dare, L., \& Nowicki, E. (2018). Strategies for inclusion: Learning from students' perspectives on acceleration in inclusive education. Teaching and Teacher Education, 69, 243-252. https:/ / doi.org/10.1016/j.tate.2017.10.017

Dunn, R., Honigsfeld, A., Doolan, L. S., Bostrom, L., Russo, K., Schiering, M. S., ... Tenedero, H. (2009). Impact of learning-style instructional strategies on students' achievement and attitudes: Perceptions of educators in diverse institutions. The Clearing House: A Journal of educational strategies, issues and ideas, 82(3), 135-140. Google Scholar

Harjaningrum, A. T., \& Inayati, D. A. (2007). Peranan orang tua dan praktisi dalam membantu tumbuh kembang anak berbakat melalui pemahaman teori dan tren pendidikan. Jakarta: Prenada. Google Scholar

Hawadi, Reni Akbar. (2004). "Stres di Bidang Akademik pada Siswa Program Percepatan Belajar". Jurnal Pendidikan dan Kebudayaan, No. 48, Tahun ke-10, Mey 2004. Google Scholar 
Jaggars, S. S., Hodara, M., Cho, S.-W., \& Xu, D. (2015). Three accelerated developmental education programs: Features, student outcomes, and implications. Community College Review, 43(1), 3-26. Google Scholar

Kotler, Philip. (1997). Dasar-dasar Pemasaran. Jakarta: Prenhallindo.

Kruel, D., Horne, K. Van, Steenis, E. Van, \& Penuel, W. R. (2018). Interaction The material and social constitution of interest. Learning, Culture and Social Interaction, (April), 0-1. https://doi.org/10.1016/j.lcsi.2018.04.010

Landau, K., Hodges, T. S., \& Mctigue, E. M. (2019). A validation program for the Self-Beliefs, Writing-Beliefs, and Attitude Survey: A measure of adolescents motivation toward writing. Assessing Writing, 39(December 2018), 64-78. https:/ / doi.org/10.1016/j.asw.2018.12.004

Levisen, C. (2016). The social and sonic semantics of reggae : Language ideology and emergent socialities in postcolonial Vanuatu. Language \& Communication, 1-15. https:/ / doi.org/10.1016/j.langcom.2016.08.009

Moser, A., \& Korstjens, I. (2018). Series: Practical guidance to qualitative research. Part 3: Sampling, data collection and analysis. European Journal of General Practice, 24(1), 9-18.

https:/ / doi.org/10.1080/13814788.2017.1375091

Murray, D. W., Rabiner, D. L., Kuhn, L., Pan, Y., \& Sabet, R. F. (2018). Investigating teacher and student effects of the Incredible Years Classroom Management Program in early elementary school. Journal of School Psychology, 67, 119-133. https:// doi.org/10.1016/j.jsp.2017.10.004

Ohlsson, R. (2018). Student-teacher conferencing in Swedish upper secondary school: Dimensions of dominance and relations between perspectives in institutional discourse. Learning, Culture and Social Interaction, (December 2017), 0-1. https:/ / doi.org/10.1016/j.lcsi.2018.03.010

Post, T., \& Molen, J. H. W. Van Der. (2018). Do children express curiosity at school ? Exploring children 's experiences of curiosity inside and outside the school context ${ }^{2}$. Learning, Culture and Social Interaction, (January), 0-1. https:// doi.org/10.1016/j.lcsi.2018.03.005

Raia, F. (2018). Learning, Culture and Social Interaction Identity, tools and existential spaces. Learning, Culture and Social Interaction, (April), 0-1. https:// doi.org/10.1016/j.lcsi.2018.04.014

Rivers, D. J., \& Ross, A. S. (2018). Interaction Communicative interactions in foreign language education: Contact anxiety, appraisal and distance. Learning, Culture and Social Interaction, 16(October 2017), 20-30. https:/ / doi.org/10.1016/j.lcsi.2017.09.001 
Rumsey, B. A. (2018). The sociocultural dynamics of indigenous multilingualism in northwestern Australia. Language \& Communication, 1-11. https:/ / doi.org/10.1016/j.langcom.2018.04.011

Singer, R. (2018). A small speech community with many small languages: The role of receptive multilingualism in supporting linguistic diversity at Warruwi Community ( Australia ). Language \& Communication, 1-17. https:/ / doi.org/10.1016/j.langcom.2018.05.002

Sutopo. (2002). Metodologi Penelitian Kualitatif. Surakarta: UNS Press.

Swastha, Basu. (2007). Azas-azas Marketing. Yogyakarta: Liberty Yogyakarta.

Vanderheyden, K., \& De Baets, S. (2015). Does cognitive style diversity affect performance in dyadic student teams? Learning and Individual Differences, 38, 143-150. https:// doi.org/10.1016/j.lindif.2015.01.006

Weber, K. E., Gold, B., Prilop, C. N., \& Kleinknecht, M. (2018). Promoting preservice teachers' professional vision of classroom management during practical school training: Effects of a structured online- and video-based self-reflection and feedback intervention. Teaching and Teacher Education, 76, 39-49. https:// doi.org/10.1016/j.tate.2018.08.008

Yenice, N., \& Aktamış, H. (2010). Determination of multiple intelligence domains and learning styles of the teacher candidates. Procedia - Social and Behavioral Sciences, 2(2), 3274-3281.

https:// doi.org/10.1016/j.sbspro.2010.03.501

\section{Copyright Holder :}

(c) Huda, M. (2019)

First Publication Right :

() Jurnal Iqra' : Kajian Ilmu Pendidikan

This article is under:

(우)(2) 